ANL $/$ RP -76.518

DE92 017239

\title{
ENVIRONMENTAL EXTERNALITIES: AN ASEAN APPLICATION TO COAL-BASED POWER GENERATION
}

\section{EXTRACT}

\section{DISCLAIMER}

This report was prepared as an account of work sportsored by an agency of the Unitad States Government. Neither the United States Government nor any agency thercof, nor any of their employees, makes any warranty, express or implied, or assumes any legal liability or responsibility for the acculacy, completeness, or usefulness of any informetion, apparatus, product, or process disclosed, or represents that its use would not infringe privately owmed rights. Refer. ence herein to any coecific commercial product, process, or service by trade name, trademark, manufacturer, or otherwise does not necessarily constitute or imply its endorsement, rexornmendation, of favoring by the United States Government or any agency therewt. The views and opinions of authors exprissed herein do not necessarily state of reflect those of the United States Governmemt or any agency thereor.

June 1992

\section{U.S. Agency for International Development} Office of Energy and InfrastructureATER 


\section{ENVIRONMENTAL EXTERNALITIES: AN ASEAN APPLICATION TO COAL-BASED POWER GENERATION ${ }^{1}$}

\section{RATIONALE FOR CONTROLLING EMISSIONS}

Significant benefits to human health that result from emissions control programs may justify the costs of pollution control policies. Many scientists, economists, risk analysts, and policymakers believe that comparisons of the benefits (in monetary value) with the costs of pollution control demonstrate that the U.S. stationary source, air emissions control program is justified (Freeman 1982). This justification is based upon pronounced benefits to human health, especially from controlling suspended particulates and sulfur compounds.

Market decisions are usually made on the basis of a consideration of traditional costs such as capital, operating and maintenance, fuel costs, and fixed charges. Social costs, which could be significant, are not incorporated explicitly into such decisions. These social costs could result in a net reduction in the welfare of individuals, and of society as a whole. Because these social costs and their effects are not represented in the price of energy, individuals have no way to explicitly value them; hence, they remain unaccounted for in market decisions (Finnell et al. 1990). By accounting for external costs, the selection of energy sources and production of energy products can lead to an equilibrium, where the total cost of energy and energy products, together with the resulting social costs, can be brought to an economic minimum.

The concept of an air emissions control program is of interest to the ASEAN countries (Brunei, Indonesia, Malaysia, the Philippines, Singapore, and Thailand) and their governments, especially if such a program could be justified in cost-benefit terms and shown to be directly applicable to ASEAN conditions. It is the intent of the effort described herein to demonstrate that technical options are available to control emissions from coal-based, electric power plants and that the costs of these options may be justified in cost-benefit terms.

\section{SCOPE OF PROJECT}

All energy conversion technologies pose some risk to society. Economists and social scientists continue to develop monetary values to represent loss of life, illness, global warming, decreased visibility, acid rain, and other consequences of electricity production. These monetary values have been translated to emissions through consideration of dose-response relationships ${ }^{2}$ and similar cause-and-effect principles.

1 Work performed by C.B. Supunar and Y.L. Gillette of Argonne National Laboratory, Environmental Assessment and Information Sciences Division, International Coal and Technology Studies, for the U.S. Agency for International Development, Office of Energy and Infrastructure, under a participating agency servire agreement with the U.S. Department of Energy.

2 "The term dose-response relationship refers to the proportion of a given population that exhibits $\&$ spocified response as a function of the dose (or concentration) of the toxic substance. Typically, a dose-response curve will exhibir a cumulative normal or $S$ shape, since some individuals will be relatively sensitive to the substance (and thus exhibit the response at low concentrations), while other individuals will be relatively insensitive (and thus not exhibit the response until the concentrations are quite high)" (Lave and Seskin 1977). 
As a result of increased public pressure and evolving regional, national, and international regulatory requirements, electric utility authorities around the globe are becoming more cognizant of environmental issues related to electric power production. However, the concerns related to environmental issues seem to be limited to ensuring regulatory compliance and incorporating the additional costs into the cost of electricity, with little evaluation of the long range impacts or future consequences of the emissions or residuals. An additional issue is that the externality values that have been used, to date, to evaluate and compare various options pose tremendous uncertainty.

The work presented in this extract was undertaken to illustrate, through example, how the costs and benefits of controlling emissions ... specifically those from new, advancedtechnology, coal-based, electric-power plants in the ASEAN region -- might be considered. Although the basic methodology developed for this effort can be applied in general, the specific examples discussed herein are for Indonesia and Thailand and their use of indigenous and imported coals. Nevertheless, as new technologies designed to be more environmentally benign than current technologies begin to enter the commercial marketplace, the simple yet quantitative techniques developed for this project will be available to compare the various options.

More importantly, the work represented by this extract could be extended easily to coalbased retrofit applications and otlier fuel comparisons. Because the commissioned project scope did not provide for consideration of these topics at this time, they are not addressed here. It does not address emissions, discharges, or pollutants other than those dispersed by air (i.e., it does not cover waterborne emissions or those related to land use). Nor does it consider the whole fuel cycle -- mining, transportation, generation. waste disposal, etc.; comparisons are made only or coal-based technologies, thereby cancelling out some factors that could be important in comparisons of technologies using different fuels.

\section{EXTERNALITIES}

The term extermality may be defined in a number of ways. Recent examples are as follows:

1. A societal cost or benefit which is not rejlected in the price of an activity, which is not limited to the environment, but which should be of concern. to the decision maker when he makes decisions aboul how much to pollute, how to control emissions, and what price to charge for his products (Joskow 1991).

2. A benefit or cost borne by an individual(s) who is (are) not responsible for making a specific decision; in other words, a benefit involuntarily received by people who did not pay for it or a cost imposed on people who do not get any compensation (Easterling et al. 1990).

3. An external or social cost related to any unpriced impacts created in the process of energy production and use, typically in the form of 
environmental damage, adverse health effects, and materials damage (Finnell et al. 1990).

Historically, the market price of conventional energy has not fully accounted for all the resultant external costs imposed on society. Emissions trading, taxes, other pricing modes, or combinations thereof would internalize some of the cost, thereby reducing the cost of an externality. But electricity-generating bodies do not usually take into account the magnitude of costs imposed on the society when they consider electricity pricing. Nevertheless, externalities, social costs, are rapidly becoming priorities in electricity generation considerations because of:

- Economic growth and a concomitant expansion in electricity dernand and its environmental impacts;

- A greater scientific understanding of external impacts;

- Improved methods of estimating the actual costs of these external impacts;

- The emergence of institutional mechanisms, such as least-cost planning and competitive bidding; and

- A much broader range of technological choices available to utilities (at varying costs) to mitigate many externalities.

To value externality costs, or "internalize" them into the decision process, (1) impacts must be identified and quantified and (2) values for these impacts must be developed. Attempting to fully describe the entire range of effects in the electric power processes is difficult in itself. But placing a value on each individual effect is considerably more difficult, particularly because these costs fall outside the normal market pricing system, so real market-cost information is usually not available (Boras et al. 1990).

In considering and applying externality costs, first, the necessary dose-response and physical damage functions ${ }^{3}$ involved need to be identified and quantified. Second, the validity of the economic value of staristical lives, ${ }^{4}$ a very controversial concept, needs to be considered and accepted. Third, the appropriate economic data need to be applied in deliberations, even though in general, these data are costly and difficult to gather. And, fourth, even with the

3 "A mathematical relationship expressing an estimate of the number and kind of physical effects resulting from exposure to some quantity of a substance; typically expressed as the number of deaths (or some other response) resulting from an annual exposure to some pollutant (typically given in micrograms per cubic meter per year)" (Ottinger et al. 1991).

4 "The economic value of environmental risks can be based either on the costs of avoiding the risk, the 'control costs,' or the costs of the damage imposed on society by the risk, the 'damage casts.'" Because the "risk to life (i.e., a statistical life) must be given a dollar value does not mean that loss of (an individual) life is treated as a strictly economic commodity... The inadequacy of current macroeconomic theory to analyze risks to human life and the environment, and the need for a new vision of ecological economics" is described by Daly (1990)

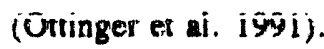


appropriate data, the fact that significant uncertainty and imprecision in the estimates will continue to exist needs to recognized (Freeman 1982).

Accurately attributing costs to their sources is not yet a finely developed science, and this situation may influence which parameters are selected. Values have been applied to:

1. the costs of environmental damage -- the costs of the damages inflicted on society by pollutants -- and

2. the costs of technology control -- the cnsts of controlling or mitigating pollution damages.

Moreover, the specific definitions or assumptions made introduce significant complexity into the calculation of externality costs, and certain costs are traded off against other costs, thus affecting which impacts are mitigated (Boras et al. 1990). Nevertheless, externalities are being quantified, valued, and considered currently by utility commissions. These environmental externalities have focused specifically on the impact of electricity generation on:

- Humans (morbidity and mortality);

- $\quad$ Crops, forests, and fisheries (losses and damages);

- Materials (corrosion and soiling); and

- Climate (change), recreation (diminishment), and visibility (impairment).

But the largest contributions to environmental costs that electricity generation imposes on society are those resulting from the risks to human health (i.e., increased risk of mortality and morbidity, including acute effects, exacerbation of chronic illness, and increased risk of developing chronic disease).

A significant volume of research involving environmental externalities exists along these lines. All of these studies assume that environmental risks imposed by energy resources result in costs paid by someone, regardless of whether estimates of those costs are quantified. Moreover, these costs are extremely difficult to calculate in terms of damage determined on the basis of valuations of life and in terms of nonmonetized costs like valuation of recreational/cultural facilities. Thus, valuation of environmental externalities is considered most difficult and is perceived by many researchers in the field as a discipline in its infancy, even though the concept has been around for decades (Lave 1991; Freeman 1985; Joskow 1991).

\section{VALUATION OF ENVIRONMENTAL EXTERNALITIES}

To quantify the relationship between power plant emissions from electricity generation and valuation of deleterious effects, several functional relationships must be established and specified (Figure 1), such as: 


\section{FIGURE 1. THEORETICAL APPROACH}

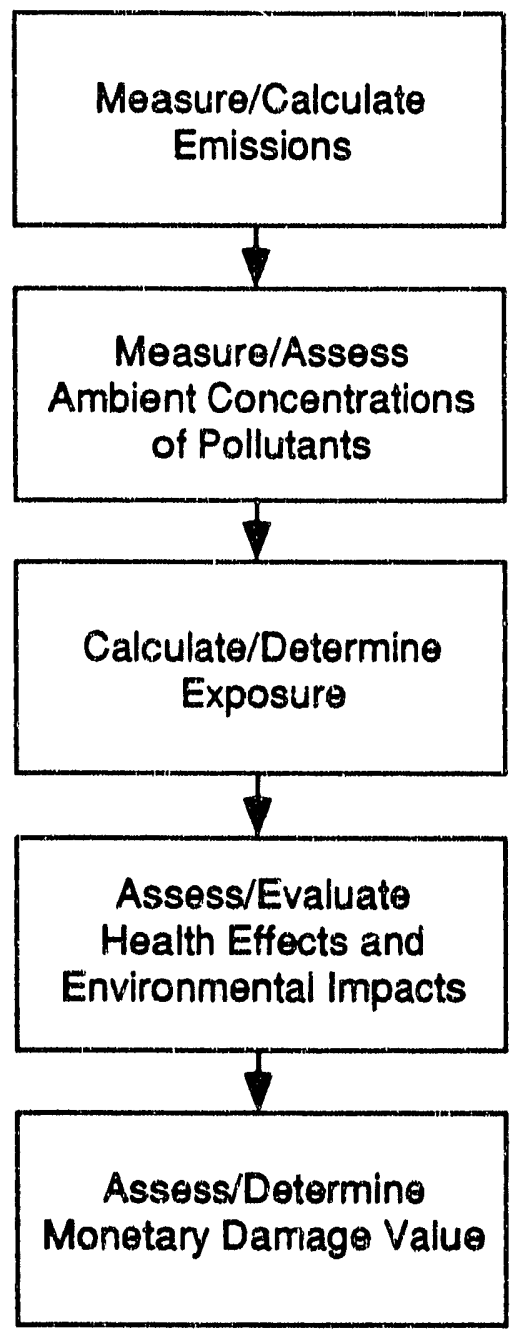

1. The relationship between specific power plant emission quantities and their resulting ambient pollution concentrations;

2. The relationship between ambient pollution concentrations and their health/environmental burden;

3. The relationship between health/environmental burden and any and all physical or biological effects; and

4. The relationship between physical or biological effects and their monetary valuation.

Relationship 1 includes the dispersion and transport of point source emissions, because these emissions become part of the ambient air quality. The health/environmental burden in Relationship 2 specifically refers to the level of exposure or dose that affects living organisms, materials, and the biosphere in general. The physical or biological effects in Relationship 3 
refer to specific health effects, health risks, and environmental impacts, such as death, injury, respiratory ailments, slower plant growth, loss of habitat, materials corrosion or soiling, and degradation to scenery. In Relationship 4, monetary valuation -- according to the willingness to pay or the willingness to be compensated for the risk accepted voluntarily -- refers to the methods that may be used to assign values to the predicted changes in mortality or morbidity, etc. Any approach to measuring health/environmental costs/benefits involves some method of determining these relationships (Freeman 1979; Ottinger et al. 1990).

To complicate matters even more, damages are site specific. Any health-related damages depend on the number of people exposed and the composition of the exposed populations (in terms of age, existing infirmities, living conditions, social habits, etc). Hence, health/ environmental damages can vary considerably from site to site, depending on:

- The location of the source relative to the population;

- The area's meteorology and topography which influences pollutant dispersion; and

- The type and amount of vegetation and the number of bodies of water in the area and their ability to absorb the pollutants generated (Ottinger et al. 1990).

The relationship between a particular site's population density and ambient air pollution concentrations is critical in that:

- The size of the affected population affects the total number of incidences of premature death and morbidity, which critically affects the cost (externality value) of pollution (by specific pollutant);

- The amount of material exposed is often assumed to be proportional to the size of the exposed population; and

- Visibility costs are calculated on a per capita basis, then multiplied by the total population (Ottinger et al. 1990).

\section{ENVIRONMENTAL EXTERNALITIES RESEARCH}

\subsection{Studies on Air Pollutants That Affect Human Health}

Many air pollutants affect human health, generally by affecting respiratory functions and causing symptoms such as impaired breathing, coughing, chest tightness, and reduced productivity and activity. Significantly high levels of air pollutants are generally associated with altered pulmonary ventilation (especially in children, the aged, and the infirmed), increased frequency and severity of asthmatic attacks, increased prevalence of chronic respiratory disease, and increased mortality. 
Recognized control methods have generally focused on suspended particulates and sulfur oxide $\left(\mathrm{SO}_{x}\right)$ emissions to date. Sulfur dioxide $\left(\mathrm{SO}_{2}\right)$ itself is not generally believed to be one of the major causes of air-pollution-related health effects. But $\mathrm{SO}_{2}$ forms sulfates and acid aerosols that are considered harmful above certain ambient levels. More importantly, particulates (especially those less than $: 0$ microns in diameter) are most often recognized as the major causes of air-pollution-related health effects. Nitrogen oxides $\left(\mathrm{NO}_{\mathrm{x}}\right)$, although not considered harmful of themselves, form ozone in subsequent chemical reactions during the transport and dispersion phase. At high levels, ozone is reported to cause severe damage to human health, vegetation, and materials (Ottinger et al. 1990).

Lave and Seskin (1977) used multiple regression techniques to investigate the relationships between a variety of air pollution variables and mortality rates. The air pollution variables they used were intended to represent long-term or chronic exposure for typical residents of U.S. urban areas.

Pollution measures were used in regressions, along with other possible causal variables, to explain the mortality rate for each urban area studied. They found a quantitative association between air pollution and morbidity and mortality. Furthermore, their evidence became the first to support the hypothesis that higher exposures to air pollutants lead to higher mortality rates (Freeman 1979; Lave and Seskin 1977). Recently, Worldwatch reported that in cities like Athens, Bombay, and Beijing, on days with severe air pollution, death rates were markedly higher (French 1990).

\subsection{Studies on Valuing Health Risks}

In the last two decades, many studies have been conducted to value health risks, specifically those from electricity generation. Many of these studies base their values on wage/risk compensation. The health risk values per statistical life ${ }^{5}$ range from $\$ 440,000$ to $\$ 12,800,000$ (all adjusted to 1989 U.S. dollars). Examples are listed in Table 1. And at least one study (Amaral 1988) has suggested and demonstrated a method for representing uncertainty, specifically to aid policymakers in making policy decisions about health risks from electricity generation.

\subsection{Studies on Monetizing Environmental Externalities}

Chernick and Caverhill (1991) provide a rationale for monetizing externalities. They suggest that estimating a monetary value for environmental externalities provides an

5 "Health risk values are often expressed as values per human life. This is convenient but inaccurate terminology. Aggregating values to a single life facilitates comparison, but it creates the impression that human life itself is being valued. Risk values are typically calculated for very small risks. An analyst may delermine, for example, that each increment of risk of $1 / 100,000$ probability of fatality has a value of $\$ 40$. If that risk were imposed on a population of 100,000 , it would be expected that one person would die. Since that amounts to 100,000 people each with a $\$ 40$ value, the total risk value would be $\$ 4,000,000$. Thus, the value for the statistical life would be $\$ 4,000,000^{*}$ (Ottinger et al. 1991). This term is also discussed by Freeman (1982). 
approximation of the societal value of reducing impacts on human health and the environment from electricity generation. They make these estimates of monetary values for environmental externalities not from direct damage estimates, but rather from indirect proxies. Through monetization, these externalities are expressed as a cost per unit of the externality, such as $\$ /$ ton of emissions. Their preferred technique is to calculate the implied valuation through the estimation of the marginal (i.e., the highest) cost of abatement -- the implied societal value of reduction of the pollutant, from the maximum cost society has committed (or appears about to commit) to pay for reductions.

\begin{tabular}{||l|r|r||}
\hline \multicolumn{2}{||l||}{$\begin{array}{l}\text { TABLE 1. RESEARCH STUDIES CONDUCTED TO VALUE HEALTH RISKS } \\
\text { FROM ELECTRICITY GENERATION }\end{array}$} & \multicolumn{2}{|c|}{$\begin{array}{r}\text { Health Risk Value per Statistical Life } \\
\text { (1989 U.S. \$) }\end{array}$} \\
\hline \hline & $\begin{array}{r}\text { Low Value of Range } \\
\text { or Point Value }\end{array}$ & High Value of Range \\
\hline Smith 1976 & $9,400,000$ & \\
\hline Thaler and Rosen 1976 & 700,000 & \\
\hline Viscusi 1979 & $3,600,000$ & \\
\hline Brown 1980 & $1,300,000$ & $4,900,000$ \\
\hline Black and Niehaus 1980 & 500,000 & $1,900,000$ \\
\hline Olson 1981 & $9,100,000$ & 775,000 \\
\hline Shuman and Cavanagh 1982 & 440,000 & \\
\hline Viscusi 1983 & $8,500,000$ & $4,400,000$ \\
\hline Schulze et al. 1983 & 455,000 & $12,800,000$ \\
\hline ECO Northwest 1987 & $3,300,000$ & $1,340,000$ \\
\hline Moore and Viscusi 1988a & $4,600,000$ & \\
\hline Moore and Viscusi 1988b & $5,300,000$ & $6,400,000$ \\
\hline Kowalczyk et al. 1988 & $11,000,000$ & \\
\hline
\end{tabular}

In contrast to the Chernick and Caverhill proxy value estimation approach, direct damage cost estimates have been made for environmental externalities such as air and water pollution. The relevant effects have included impacts on:

1. Human life and health;

2. Domesticated plants and animals, such as commercial forests, crops, lawns, and livestock; 
3. Wild plants and animals in a variety of habitats;

4. Nonliving materials, such as those exposed on buildings, at archaeological and historical sites, on monuments, on vehicles, and in natural landforms; and

5. Human comfort and pleasure, including effects of noise levels, visibility, and odors.

\section{SIMPLIFIED APPROACH FOR VALUATION OF ENVIRONMENTAL, EXTERNALITIES IN ASEAN COUNTRIES}

Mindful of the results and qualifiers of the foregoing and other studies, the authors propose a simplified approach in determining monetary damage values regarding environmental externalities (Figure 2).

\section{FIGURE 2. SIMPLIFIED APPROACH DERIVED FROM A THEORETICAL APPROACH}
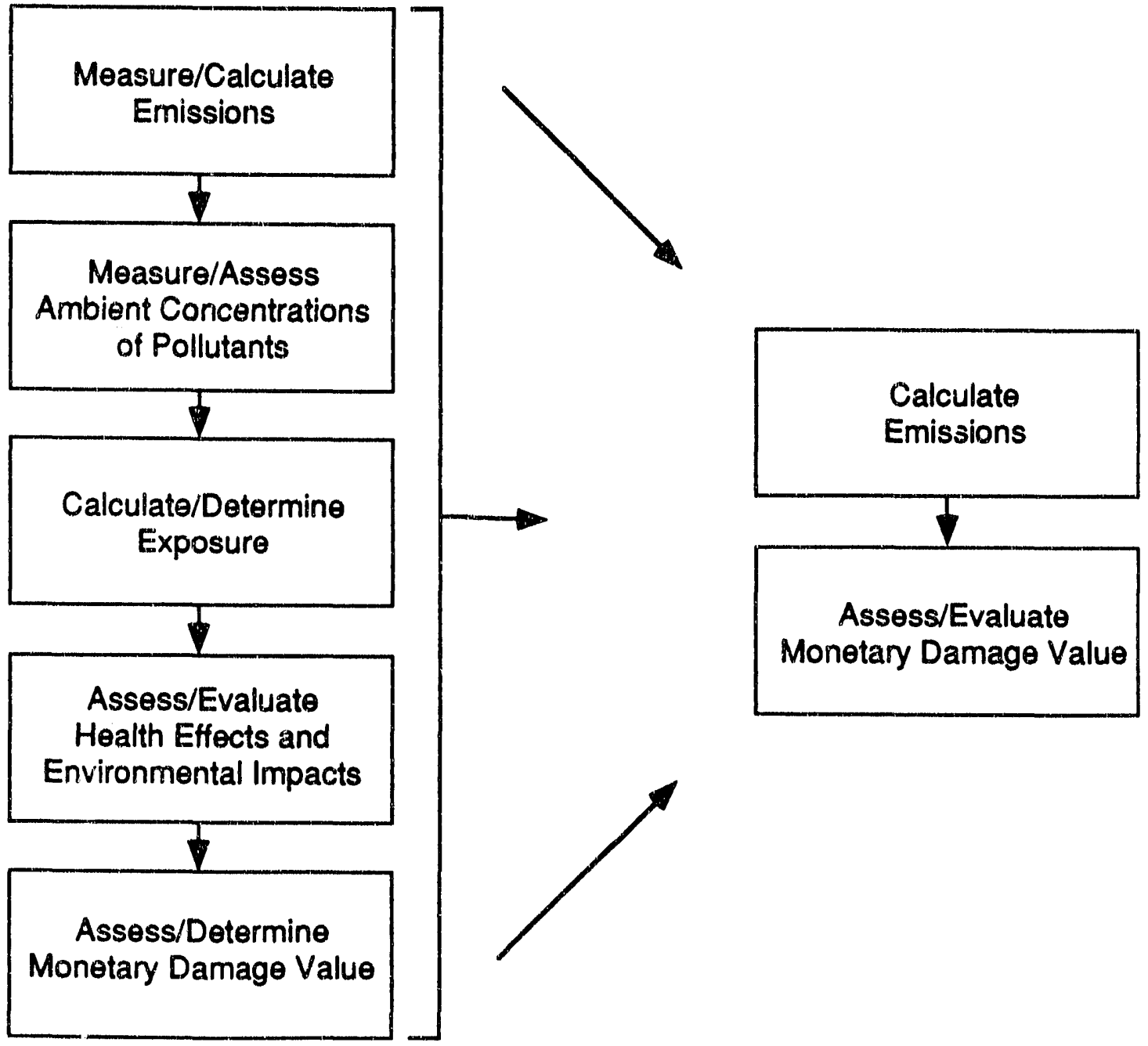
1. Calculate power-plant-generated emissions from various electric power generation options (coal-fired), recognizing their inherent uncertainties. These calculated emissions would be dependent on plant type, plant age, fuel type, fuel grade, sulfur content, installed/operating emissions technology, and plant operating parameters such as heat rate, combustion temperature, and injection options.

2. Assess the value for monetary damage to the environment, assuming conservative estiniates for point source emissions.

\subsection{Measuring ASEAN Air Quality Emissions}

The monitoring of air quality is limited in most of Asia. With the exception of Japan, air quality in Asia has generally worsened with industrialization and the lack of effective pollution controls. Not one United Nations Environment Programme (UNEP)/World Health Organization (WHO) air quality monitoring site in Asia has yet complied with WHO standards for suspended particulates, and only half the stations met $\mathrm{SO}_{2}$ standards between 1979 and 1985. (Analogous to the WHO standards are the U.S. National Ambient Air Quality Standards [NAAQS].)

Overall, Asia is said to show no definitive trends regarding air quality; progress made in some cities to decrease certain pollutants is offset by setbacks in others. Compared with the industrialized countries (Tables 2 and 3), Asia lags far behind in controlling most air pollutants. For example, particulate levels in Manila increased more than 20\% from 1974 to 1984 (World Resources Institute 1988).

\subsubsection{Particulates}

Average and peak concentrations of particulates exceeded the air quality standards recommended by the WHO at 62 of the 73 monitoring sites in developing countries. Only eight South American monitoring sites and no Asian sites had particulate levels that fully complied with WHO standards. By comparison, about half the stations in industrialized countries were in compliance with WHO standards.

Particulate levels in some Asian cities exceeded the standards by factors of 3 to 5 . The forecast trend in particulates pollution is ambiguous, since more stations showed declines in average particilate levels but increases in peak values (World Resources Institute 1988).

During 1982-1985, Bangkok (198-243 ug/m $\left./ \mathrm{m}^{3}\right)$ Jakarta $\left(243 \mathrm{ug} / \mathrm{m}^{3}\right)$, and Manila (100$172 \mathrm{ug} / \mathrm{m}^{3}$ ) all exceeded the WHO guideline of $60-90 \mathrm{ug} / \mathrm{nm}^{3}$ by more than two to three times; Kuala Lumpur (100-112 ug/ $\left./ \mathrm{m}^{3}\right)$ also exceeded the guideline (Table 2). 


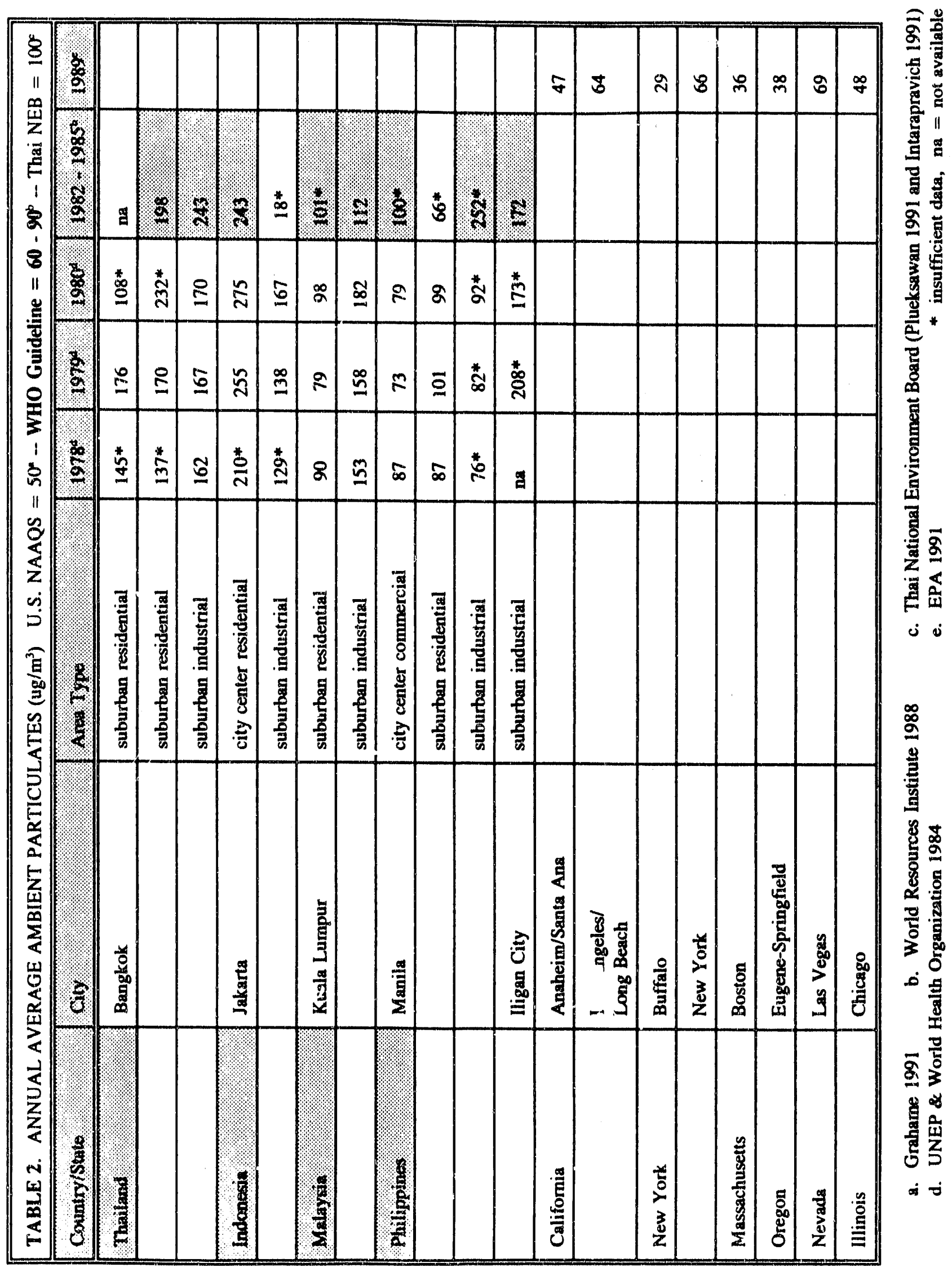









\subsubsection{Sulfur Dioxide}

Sulfur dioxide pollution levels in cities of developing countries do not appea- to be as high as particulate pollution levels; about half the stations recorded $\mathrm{SO}_{2}$ levels that excueded WHO standards. About $15 \%$ of the stations in industrialized countrie: also exceeded the standards. Trend data indicate neither a broad improvement nor a worsening of $\mathrm{SO}_{2}$ pollution; approximately equal numbers of stations reported increases and decreases in $\mathrm{SO}_{2}$ over the 19791985 period (World Resource Institute 1988).

During 1982-1985, of the ASEAN countries, only Manila $\left(61-83 \mathrm{ug} / \mathrm{m}^{3}\right)$ appears to have exceeded the WHO guideline of $40-60 \mathrm{ug} / \mathrm{m}^{3}$. However, data appear to be sparse (to nonexistent) for Bangkok and Jakarta (Table 3).

\subsection{Determinirg Environmental Externality Values for ASEAN Applications}

Many values for environmental externalities have been proposed. A partial listing is presented in Table 4. The following discussion describes the work of Lave and briefly explains why his set of values was chosen as most appropriate for ASEAN conditions.

Lester Lave, a ioneer in the field of externalities, has conducted research on the economics of energy, the economics of the environment, and environmental health and safety for more than two decades. In particular, his work on the effects of air poilution on health has been the basis for setting U.S. and state air quality standards (Lave 1991).

Lave has estimated externality values for emissions of air pollutants on the basis of marginal benefits of abatement (i.e., the dollar benefit to society in abating emissions of air pollutants). To sum up his position, externality values must be based on the marginal benefit of abntement, not on some ad hoc estimates of the marginal cost of abatement.

In the 1970s, as already mentioned, Lave and Seskin found a close and persistent relationship between total suspended particulate matter and mortality, as well as a close relationship beiween the level of sulfates (in the particulates) and mortality. The implication of the relationship is that improvements in air quality over the past two decades have had a substantial health benefit. Moreover, they found that the relationship between air pollution and health was not statistically significant for areas already attaining the U.S. primary air quality standards.

On the basis of his research, Lave believes that there are no significant heaith effects in attainment ${ }^{6}$ areas, only visibility and other adverse welfare impacts such as materials damage.

6 When an area is found to meet the U.S. NAAQS for a criteria pollutant (particulates, $\mathrm{SO}_{2}, \mathrm{CO}, \mathrm{NO}_{2}$, ozone,

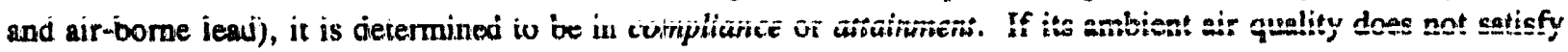
the standards, it is terned a nonattainment area. 


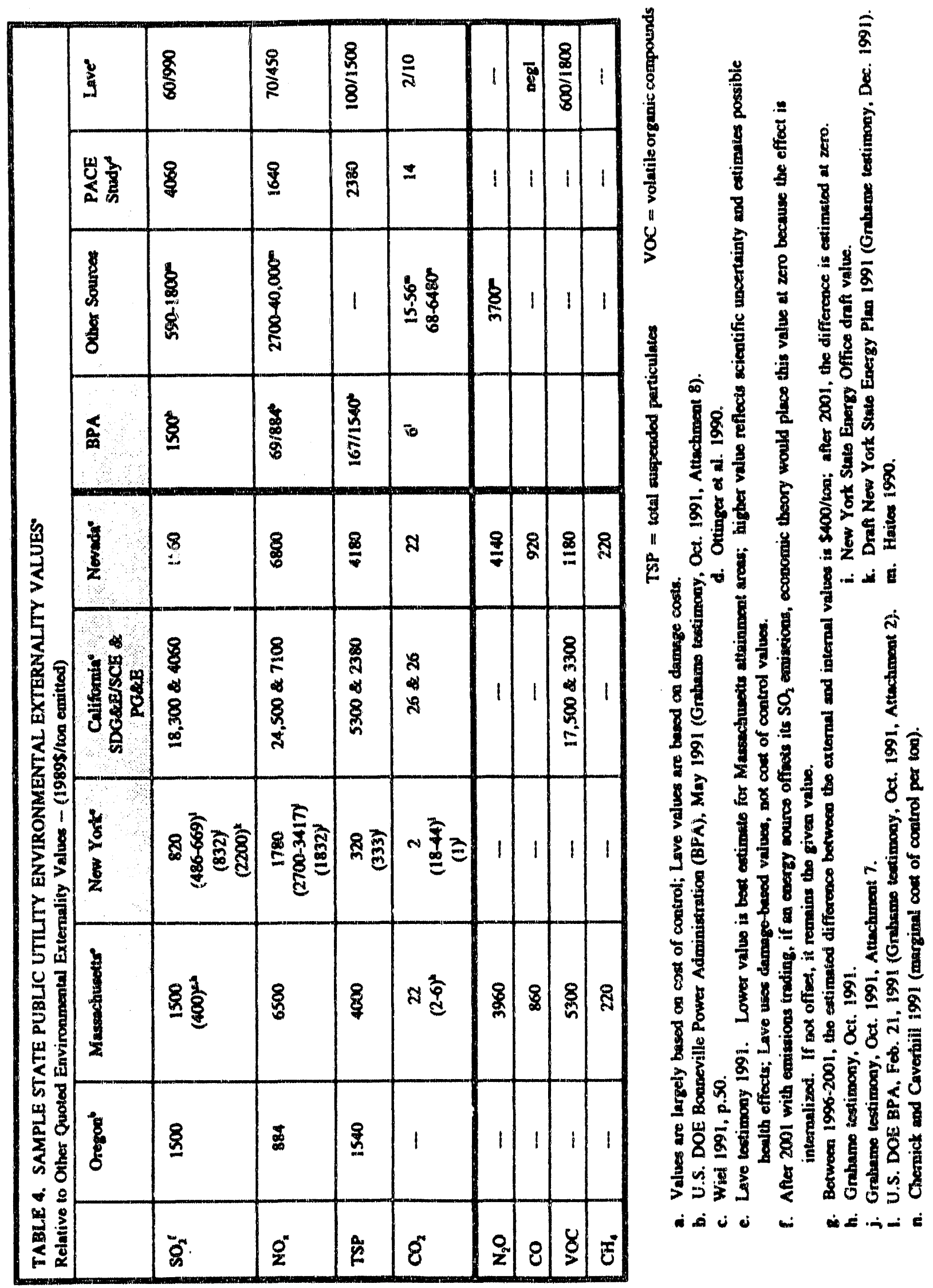


However, to reflect the large amount of scientific uncertainty, specifically regarding health effects, Lave has also developed a set of higher values for externalities. Lave offers his "bestguess" estimates as well as his "higher" estimates of the marginal benefits of abating (criteria) air pollutants for applicability in the state of Massachusetts, an area that is in attainment (except for ozone). He offers these values to guide pollution abatement policy and the choice of tochnologies.

A comparison of the Lave estimates with others in Table 4 shows that the former are lower than most (i.e., they may be considered conservative estimates of the value of environmental externalities to be used in attainment areas). Consideration of several factors, including the fact that the ASEAN region can generally be considered to be a nonattainment area where health impacts can be expected, the authors have elected to use the higher, but still conservative, Lave externality values in the analysis of CCTs in ASEAN applications. Use of such values in evaluating CCTs could thus reflect the minimum benefits attributable to these technologies. ${ }^{7}$

To emphasize our choice of environmental externality values, the higher Lave values are used because:

1. Direct damage estimates are considered by many researchers in the field (and by the authors) to be more reflective of the activity occurring, rather than using indirect proxy values such as those put forth by Chernick and Caverhill.

2. Lave demonstrates a wealth of experience in the fields of health risk assessment and environmental externalities and has shown tremendous judgement over the years (Grahame 1992).

3. Because the Lave environmental externality values are very conservative estimates of health-related damage, the findings will err on the conservative side (i.e., the environmental benefits to be obtained by considering environmental externalities will actually be greater than that reported).

7 To consider the concept of environmental externalities more rigorously, one may need to consider the net system impacts upon addition of new units. What this suggestion means is "that equal amounts of capacity will result in different net emissions because the capacity types have different capacity factors and, therefore, (will) displace different amounts of existing (relutively dirty) capacity" (Grahame 1992). "Continued operation of existing power plants and the dynamic(s) of new' supply technology development ..." may provide "... many cost-effective emissions reduction opportunities. ... A superior approach is to take a systemic perspective on the emissions reduction challenge, and compare complete resource portfolios rather than options al the margin" (Andrews 1991). 


\section{APPLYING ENVIRONMENTAL EXTERNALITIES TO ASEAN COUNTRIES}

\subsection{Scenarios Developed}

The method developed is being applied to new, coal-based, electric power plants sited in Indonesia and Thailand. The specific objective is to compare plants that may use advanced technologies and that will achieve high levels of emission control with a reference case, a pulverized-coal-fired plant that uses with no flue gas desulfurization (FGD) treatment other than a moderate level of particulate control. Examination of the generation requirements for each country has indicated that a new plant in Indonesia would be likely to have a generating capacity of approximately $600 \mathrm{MW}$, while Thailand would be more likely to build a plant of about $300 \mathrm{MW}$. Hence, these plant sizes are used in this analysis. The plants considered in this analysis include the reference case option and four generic clean coal technologies (CCTs), as follows:

1. A pulverized-coal (PC)-fired plant with no $\mathrm{SO}_{2}$-emission controls and moderate particulate control -- the reference case;

2. A PC-fired plant with $\mathrm{SO}_{2}$-emission control and a higher level of particulate control -. PC/FGD;

3. An atmospheric fluidized-bed combustion plant -- AFBC;

4. A pressurized fluidized-bed combustion plant -- PFBC; and

5. An integrated coal gasification combined-cycle plant -- IGCC.

Estimates of the reduction levels and emission rates for air pollutants from these generic coal technologies are presented in Table 5. These values are considered representative of those for a family of variations within each technology, and serve as the base case estirnates in this analysis.

\begin{tabular}{|l|r|r|r|r|r|}
\hline TABLE 5. BASE CASE EMISSION RATES AND REDUCTION LEVELS BY TECHNOLOGY \\
\hline Emission & $\begin{array}{c}\text { Uncontrolled } \\
\text { Pulverized Coal }\end{array}$ & $\begin{array}{c}\text { Controlled } \\
\text { Pulverized Coal }\end{array}$ & AFBC & PFBC & IGCC \\
\hline $\mathrm{SO}_{2}(\%)$ & no controls & 80 & 80 & 90 & 95 \\
\hline $\mathrm{NO}_{\mathrm{x}}(\mathrm{ppm})$ & 800 & 400 & 150 & 150 & 150 \\
\hline $\mathrm{TSP}(\%)$ & 80 & 90 & 90 & 95 & 99.99 \\
\hline $\mathrm{CO}_{2}(\mathrm{lb} / \mathrm{kWh})$ & 2.0 & 2.1 & 2.2 & 1.9 & 1.9 \\
\hline $\mathrm{N}_{2} \mathrm{O}(\mathrm{pprn})$ & 1 & 1 & 1 & 1 & 1 \\
\hline $\mathrm{CO}(\mathrm{ppm})$ & 120 & 120 & 200 & 170 & 5 \\
\hline
\end{tabular}


The values for $\mathrm{SO}_{2}$ and particulate control given in Table 5 do not necessarily represent the full capabilities of the advanced technologies. Instead, they are intended to represent improvements over the reference PC-fired plant, assumed for ASEAN applications. Values for $\mathrm{CO}_{2}$ emissions are based on a release rate of 205 pounds per million British thermal units (Btu) of heat input ( $369 \mathrm{~kg} /$ million kilocalorie) adjusted by the efficiency of the technology and an assumed amount of limestorie required for $\mathrm{SO}_{2}$ control.

Several coals were examined in this analysis. These coals reflect the range of possible fuel qualities for these specific applications. Two sets of indigenous and two sets of imported coal qualities (typical of an Australian coal and a U.S. Appalachian coal) are considered for each country. Relevant coal characteristics are presented in Table 6.

\begin{tabular}{|l|c|c|c|c|c|c|}
\hline TABLE 6. REPRESENTATIVE COAL QUALITY CHARACTERISTICS \\
\hline Coal/Lignite & Rank & $\begin{array}{c}\text { Calorific } \\
\text { Value } \\
(\text { Btu/lb) }\end{array}$ & $\begin{array}{c}\text { Calorific } \\
\text { Value } \\
(\mathrm{kcal} / \mathrm{kg})\end{array}$ & $\begin{array}{c}\text { Moisture } \\
(\%)\end{array}$ & $\begin{array}{c}\text { Ash } \\
(\%)\end{array}$ & $\begin{array}{c}\text { Sulfur } \\
(\%)\end{array}$ \\
\hline $\begin{array}{l}\text { Indonesia } \\
\text { Ombilin }\end{array}$ & Bituminous & 13,250 & 7360 & 4.1 & 5.6 & 1.5 \\
\hline $\begin{array}{l}\text { Indonesia } \\
\text { Pt. Arutmin }\end{array}$ & Bituminous & 11,160 & 6300 & 4.0 & 15.0 & 0.7 \\
\hline $\begin{array}{l}\text { Thailand } \\
\text { Mae Moh }\end{array}$ & Lignite & 4950 & 2750 & 34.0 & 20.2 & 0.5 \\
\hline $\begin{array}{l}\text { Thailand } \\
\text { Krabi }\end{array}$ & Lignite & 4150 & 2310 & 30.0 & 26.0 & 3.5 \\
\hline $\begin{array}{l}\text { Australia } \\
\text { New South Wales }\end{array}$ & Bituminous & 12,240 & 6800 & 3.0 & 13.5 & 0.5 \\
\hline $\begin{array}{l}\text { United States } \\
\text { Upper Froport }\end{array}$ & Bituminous & 9750 & 5420 & 4.8 & 30.2 & 1.8 \\
\hline
\end{tabular}

\subsection{Method Developed}

Traditional methods for determining the costs of electricity production involve techniques for annualizing capital expenses, incorporating operating and maintenance costs, and calculating fuel costs. These costs form the basis for establishing the price of electricity that consumers must pay. Utilities have acknowledged concerns related to environmental issues by ensuring compliance, by incorporating the additional costs of compliance into the cost of electricity, and by conducting some evaluation of the impacts or consequences of the emissions or residuals.

By combining the economic value of environmental impacts with the quantity of electricity produced per unit of emission, an environmental cost of electricity production can be determined. This cost can be expressed in the same terms as are the more traditional costs (e.g., 
U.S. cents per kilowatt hour) and can thus be combined with the traditional costs. It car also be directly compared with the traditional costs to illustrate the relative magnitudes of each cost.

For these analyses, a model was developed to estimate the traditional cost of electricity production for conditions representative of those in Indonesia and Thailand. Externality costs were also estimated through the use of the emission rates (or control levels) for the individual technologies and the externality values. These costs were added to yield a total cost for each option.

A figure of merit was developed to illustrate the benefit-to-cost ratio for each advanced option relative to the reference case. This figure of merit is equal to the benefit of reduced atmospheric emissions divided by the increase in traditional cost of electricity production. A benefit-to-cost ratio of less than 1.0 means that the benefits are less than the additional production costs, while a ratio greater than 1.0 means that the benefits exceed the additional costs. A ratio of 1.0 means that the benefits of reduced atmospheric emissions exactly offset the addition cost of electricity production.

\subsection{Study Assumptions}

In addition to the technology characteristics listed in Table 5, several economic and technical assumptions were made to allow quantitative assessments of the emission control costs and the benefits of the advanced coal technologies. An annual discount rate of $5 \%$ was selected as representative for these applications. All technologies were considered to operate as baseload plants, with capacity factors of $70 \%$ over a 30 -year lifetime. As already stated, evaluation has indicated that a $600-\mathrm{MW}$ facility would represent Indonesian new power plant requirements, while a 300-MW plant would be more typical of new construction in Thailand. The analysis herein was performed in terms of constant U.S. dollars. Basic fuel costs ranged from U.S. $\$ 6.30$ to $\$ 8.30$ per million kilocalories $(\$ 1.6-2.1 /$ million $B t u)$.

For purposes of this analysis, it was assumed that all of the additional costs of the advanced technologies, as compared with those of the reference PC plant, are attributable to environmental controls. In reality, some of these additional costs could result from the desire to make the advanced technologies more reliable and more fuel flexible. By assigning all additional costs to environmental conirol, the results of the analyses will conservatively (i.e., under) estimate the ratio of benefits to costs. Thus, the advanced technologies should provide, in practice, an environmental-benefit to environmental-control cost ratio as least as high as the values presented in this report extract, if not higher.

The environmental externality values selected for this analysis are the higher of Lave's conservative externality values, which are neither the highest nor the lowest values that could be considered. These values, however, do represent the lowest estimated environmental externality values available that include health effects. 


\subsection{Study Results}

The numerical results of this analysis include values for the traditional cost of electricity production (capital, O\&M, and fuel) and for the cost of environmental externalities. As noted earlier, a ratio of the incremental benefits due to the reduction in emissions divided by the incremental cost in the traditional cost of electricity production is used as a figure of merit for these technologies.

Results from these analyses are shown in Table 7. In every case, the results demonstrate a benefit-to-cost ratio greater than 1.0. In other words, over the variety of technology applications and coal ranks/types considered, the value of the reduction in atmospheric emissions is estimated to be greater than the additional cost that may be incurred in attaining the higher levels of emission control.

The tenefit-to-cost ratio is generally in the range of 2 to 10 , with a maximum value of 127 estimated for the IGCC application in Thailand using a good-burning U.S. Upper Freeport quality coal. Examination of Table 6 shows that this coal quality has the highest ash content of all coals considered and one of the highest sulfur contents, despite being one of the easiest to burn. Thus, the IGCC with its high control levels for each of these pollutants can produce very substantial benefits when compared with the reference power plant that has no sulfur control capability and a marginal control of particulates.

\begin{tabular}{|c|c|c|c|c|c|c|}
\hline Technology & $\begin{array}{c}\text { Ombilin } \\
\text { Conl }\end{array}$ & $\begin{array}{l}\text { Pt. Arutmin } \\
\text { Coal }\end{array}$ & $\begin{array}{c}\text { Mae Moh } \\
\text { Lignite }\end{array}$ & $\begin{array}{l}\text { Krabi } \\
\text { Lignite }\end{array}$ & $\begin{array}{l}\text { Australian } \\
\text { New South } \\
\text { Wales Coal }\end{array}$ & $\begin{array}{c}\text { U.S. Upper } \\
\text { Freeport } \\
\text { Coal }\end{array}$ \\
\hline \multicolumn{7}{|c|}{ MOONESIO } \\
\hline PC/FGD & 1.5 & 2.1 & - & - & 1.7 & 4.7 \\
\hline AFBC & 1.5 & 1.8 & - & $\ldots$ & 1.4 & 3.9 \\
\hline PFBC & 2.7 & 3.9 & -- & - & 3.3 & 9.5 \\
\hline IGCC & 3.0 & 5.2 & - & - & 4.1 & 11.9 \\
\hline \multicolumn{7}{|c|}{ 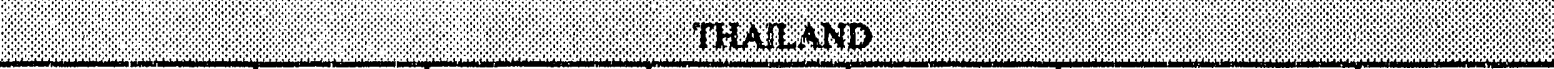 } \\
\hline PC/FGD & -- & - & 5.5 & 10.7 & 1.4 & 3.9 \\
\hline AFBC & - & - & 6.2 & 9.4 & 1.6 & 3.9 \\
\hline PFBC & $\cdots$ & -- & 11.1 & 21.0 & 3.1 & 8.7 \\
\hline IGCC & -- & -- & 38.9 & 69.6 & 28.2 & 127.3 \\
\hline
\end{tabular}

'Based on the conservative, higher, health-based Lave environmental externality values. 
A more detailed examination of these results provides some additional insight into their significance. The traditional cost of electricity production with an IGCC in Indonesia burning Upper Freeport quality coal is estimated at approximately 4.1 cents (U.S.)/kWh. The corresponding cost for the reference case pulverized coal unit is approximately 3.7 cents $/ \mathrm{kWh}$. However, the cost of the environmental externalities due to air emissions from the IGCC is approximately 1.0 cent $/ \mathrm{kWh}$ while the emissions from the reference facility have a cost of about $5.8 \mathrm{cents} / \mathrm{kWh}$. [These figures yield the benefit-to-cost ratio of 11.9 listed in Table 7 (benefit of $[5.8-1.0] /$ cost of $[4.1-3.7])$.] Thus, when the $600-\mathrm{MW}$ plant operates for a year at a capacity factor of $70 \%$, the additional cost of electricity production is less than $\$ 15$ million. However, the reduction in atmospheric emissions realized by using the IGCC rather than the reference technology reduces environmental externality costs by more than $\$ 176$ million per year.

A similar breakdown of the costs of the IGCC in Thailand, where the plant capacity is $300 \mathrm{MW}$, shows that the traditional costs are nearly equal with those of the IGCC, slightly above 4.0 cents $/ \mathrm{kWh}$, and the reference plant slightly less than that amount. However, the externality costs are 1.0 and $5.8 \mathrm{cents} / \mathrm{kWh}$ for the IGCC and reference plant, respectively. [These figures lead to the benefit-to-cost ratio of 127 listed in Table 7 (benefit of [5.8 - 1.0]/ cost of [approx. 4.0 - approx. 4.0]).] Thus, by spending less than $\$ 0.7$ million per year in additional electricity production costs, savings of more than $\$ 88$ million per year in externality costs can be realized.

\subsection{Study Sensitivities}

The environmental externality values involve considerable uncertainty with respect to the state of the science (e.g., atmospheric dispersion and health effects) and the selected economic values (e.g., the dollar value of a health impact or of visibility impairment). Nevertheless, sensitivity analyses were performed on several parameters, including capital and operating costs, values of environmental externalities, and base-case emission rates and emission control levels. Although the individual costs and benefits changed (in some cases, the estimated benefit-to-cost ratio became less than 1.0 ), the basic conclusions remain the same. These are that:

1. Significant environmental benefits are likely to accrue when using CCTs and

2. The value of these benefits will generally be much greater than the incremental cost resulting from reducing emissions.

Therefore, environmental externality values can be used as demonstrated here to make a quantitative estimate of the benefits to be derived, so that they can be compared with the cost of electricity production. 


\section{OBSERVATIONS}

A number of observations are appropriate for the analyses described herein. Several of these are briefly summarized below.

1. The concept of environmental externalities has recently received greater attention after a relative hiatus of about 10 years. Recent advances in basic knowledge and in modeling capabilities dealing with dose-response characteristics, atmospheric dispersion, medical treatment, and other factors have led to a better understanding of the impacts of pollutants. The economic value of these impacts is an area under constant investigation, and additional information in this regard is being accumulated and evaluated.

2. As demonstrated by the methodology development and application described in this extract, it is possible to express environmental externality costs in a framework that is consistent with traditional methods of determining the cost of electricity production. By doing so, it becomes possible to compare these costs and to develop a figure of merit that allows for a cost-benefit comparison that can be used to evaluate the tradeoffs that are being made. The methodology also allows traditional and externality costs to be combined in a way that is appropriate for least-cost planning and for determining life-cycle costs.

3. Under the base-case assumptions of this analysis, the CCTs were demonstrated to provide significant economic benefits (resulting from reductions in atmospheric emissions) that are greater than the incremental costs required to attain these emission reductions. These benefits were obtained even though very conservative assumptions were used in all phases of the analysis. Such assumptions involved the value of each externality, the type of atmospheric emissions (i.e., only atmospheric), and all the incremental costs of the advanced technologies being attributed to the control of atmospheric emissions. Less conservative assumptions would result in estimates with even greater benefit-tocost ratios than those presented here. 


\section{REFERENCES}

Amaral, D., 1988, Including Uncertainty in Assessments of Sulfur Oxide Health Risks, Journal of Air Pollution Control Assoc. (JAPCA), Vol. 38. No. 4, April, pp. 399-405.

Andrews, C.J., 1991, The Marginality of Regulating Marginal Investments: Why We Need A Sysiemic Perspective on Environmental Frseirlality Adders, Energy Policy, forthcoming.

Black, S.C., and F. Niehaus, 1980, Comparison of Risks and Benefits Among Different Energy Systems, in Interactions of Energy and Climate, Bach, W., J. Pankrath, and J. Williams, eds., D. Reidel Publishing Co., Dordrecht, pp. 421-436.

Boras, K., J. Finnell, T. Kennedy, K. DeGroat, 1990, Considering Social Costs in Utility Decision Making: Alternative Approaches and Implementation, Pacific Gas and Electric Company Report, Nov. 1.

Brown, C. 1980, Equalizing Differences in the Labor Market, Quarterly Journal of Economics, Vol. 94, February, pp. 113-134.

Chernick, P. and E. Caverhill, 1991, Methods of Valuing Environmental Externalities, Electricity Journal, Vol. 4, No. 2, March, pp. 46-53.

Crocker et al., 1979 [Freeman 1979 or 1982].

Daly, H., 1990, The Ecological Economics of Sustainability, International Society for Ecological Economists Conference, The World Bank, Washington, D.C., May 21-23.

Easterling, J.B., R.J. Redmond, and E. Turner, 1990, Social Issues and Challenges in the Disposal of Nuclear Waste, in High Level Radioactive Waste Management, Vol. 2, Proceedings of the International Topical Meeting, sponsored by the American Society of Civil Engineers and the American Nuclear Society, Las Vegas, Nevada, April 8-12.

ECO Northwest, 1987, Generic Coal Study: Quantification and Valuation of Environmental Impacts, for Bonneville Power Administration, Portland, OR.

Finnell, J., T.G. Kennedy, and T.E. Monk, 1990, Evaluating Externalities Related to the Energy Sector, Meridian Corp Report, prepared for PT Resource Development Consultants (REDECON) as an attachment to the Energy Pricing and Policy Study (EPPS), August 1.

Freeman, A.M., 1985, Methods for Assessing the Benefits of Environmental Programs, in Handbook of Natural Resource and Energy Economics, Vol. 1, A.V. Kneese and J.L. Sweeney, eds., Elsevier Science Publishers, Amsterdam, pp. 223-270.

Freeman, A.M., 1982, Air and Water Pollution Control: A Benefit-Cost Assessment, John Wiley and Sons, New York. 
Freeman, A.M., 1979, The Benefits of Environmental Improvemert: Theory and Practice, Resources for the Future, Inc., Johns Hopkins University Press, Baltimore, Maryland.

French, H., 1990, You Are What You Breathe, Worldwatch, May-June.

Grahame, T.J., 1992, U.S. Department of Energy, personal communications.

Grahame, T.J., 1991, testimony before the Commonwealth of Massachusetts Department of Public Utilities, Boston, Massachusetts, Oct. 4 and Dec. 1.

Haites, E.F., 1990, Introduction to the Use of Social Costs in Utility Planning and Regulation, in proceedings of the National Conference on Environmental Externalities, sponsored by the National Association of Regulatory Utility Commissioners, Jackson Hole, Wyoming, October 1-3.

Heintz, H.T., A. Hershaft, and G. Horak, 1976, National Damages of Air and Water Pollution, a report submitted to the U.S. Environmental Protection Agency (Freeman 1985).

Intarapravich, D., 1991, Coal and the Environment in Thailand, presented at Coal and the Environment; Asia 2010 Conference, sponsored by the East-West Center and the U.S. Department of Energy, Honolulu, Hawaii, July 11-12.

Jacobson, B., 1984, The Role of Air Pollution and Other Factors in Local Variations in General Mortality and Cancer Mortality, Archives of Environmental Health, Vol. 39, No. 4, August, pp. 306-313.

Jones, D.E. and P. Hanser, 1991, Environmental Externalities: An Overview of Theory and Practice, EPRI Report, CU/EN-7294, May.

Joskow, P.L., 1991, Dealing with Environmental Externalities: Let's Do It Right!, prepared for the Harvard Northeast Electric Utility Executive Conference, Killington, Vermont, Oct. 17-18.

Kowalczyk, G.S., L.B. Gratt, K.M. Conner, T.Y. Choi, and T.F. Wilson, 1988, Emissions of Air Toxics from a Coal-Fired Power Plant: Evaluating the Trade-Offs Between Public Health Risks and Emission Control Costs, annual meeting of the Air Pollution Control Association, Dallas, TX, June 19-24, published by the Air Pollution Control Association, Pittsburgh, PA.

Lave, L.B., 1991, testimony before the Commonwealth of Massachusetts Department of Public Utilities, Boston, MA, (D.P.U. 91-131).

Lave, L.B. and E.P. Seskin, 1977, Air Pollution and Human Health, Resources for the Future, John Hopkins University Press, Baltimore, Maryland.

Lin and Yu, 1976 [Freeman 1979 or 1982]. 
Moore and W.K. Viscusi, 1988a, The Quality of Adjusted Value of Life, Economic Enquiry, Vol. 26, No. 369.

Moore and W.K. Viscusi, 1988b, Doubling the Estimated Value of Life: The Implications of New Occupational Fatality Data, Journal of Policy Analysis and Management, Vol. 7.

Morris, 1979 [Freeman 1979 or 1982].

Morris, S., P.D. Moskowitz, W.A. Sevian, S.Silberstein, and L.D. Hamilton, 1979, Coal Conversion Technologies: Some Health Environmental Effects, Science, Vol. 206, pp. 654-662.

Oison, C., 1981, An Analysis of Wage Differentials Received by Workers on Dangerous Jobs, The Journal of Human Resources, Vol. 16, No. 2.

Ottinger, R.L., D.R. Wooley, N.A. Robinson, D.R. Hodas, S.E. Babb, S.C. Buchanan, P.L. Chernick, E. Caverhill, A. Krupnick, and U. Fritsche, 1990, Environmental Costs of Electricity, prepared by the Pace University Center for Environmental Legal Studies for the New York State Engineering Research \& Development Authority and U.S. DOE, Oceana Publications, New York, Wolcott, D.R., ed.

Plueksawan, W., 1991, Coal Use in the Electricity Sector of Thailand, presented at Coal and the Environment: Asia 2010 Conference, sponsored by the East-West Center and the

U.S. Department of Energy, Honolulu, Hawaii, July 11-12.

Schulze, W.D., D.S. Brookshire, and R.C. d'Arge, 1983, Economic Valuation of the Risks and Impacts of Energy Development, in Health Risks of Energy Technologies, C.C. Travis and E.L. Etnier, eds., AAAS selected symposia series, published by Westview Press, Inc. Boulder, $\mathrm{CO}$ for the American Association for the Advancement of Science,

Washington, D.C., pp. 229-278.

Shuman, M. and R. Cavanagh, 1982, A Model Conservation and Electric Power Plan for the Pacific Northwest, App. A., Northwest Conservation Act Coalition, Seattle, Washington, November.

Small, 1977 [Freeman 1979 or 1982].

Smith, V.K., 1976, The Measurement of Mortality and Air Pollution Relationships, Environment and Planning, Vol. 8, pp. 149-162.

Szpunar, C.B., E.C. Winegartner, C.J. Lin, and R.A. Nadkarni, 1980, The Fate of Trace Elements in Coal Combustion, Exxon Research and Engineering, Baytown, Texas, COR.24KW.80, December.

Thaler, R. and S. Rosen, 1976, The Value of Saving a Life: Evidence from the Labor Market, in Household Production and Consumption, N. Terkeckyj, ed., Columbia Press, New York. 
Thibodeau et al., 1980 [Freeman 1979 or 1982].

U.S. Environmental Protection Agency, 1991, National Air Quality and Emissions Trends Report, 1989, Office of Qir Quality, Planning and Standards, Technical Support Division, Research Triangle Park, NC, EPA-450/4-91-003, February.

Viren, 1978 [Freeman 1979 or 1982].

Viscusi, W.K., 1989, Toward a Diminished Role for Tort Liability: Social Insurance, Government Regulation, and Contemporary Risks to Health and Safety, Yale Journal on Regulation, Vol. 6, No. 1, Winter.

Viscusi, W.K., 1983, Risk by Choice: Regulating Health and Safety in the Workplace.

Viscusi, W.K., 1979, Employment Hazards: An Investigation of Market Performance.

Wadell, T.E., 1974, The Economic Damages of Air Pollution, Office of Water Resources Research, U.S. Environmental Protection Agency, May.

Wiel, S., 1991, The New Environmental Accounting: A Status Report, Electricity Journal, Vol. 4, No. 9, November, pp. 46-54.

World Health Organization, 1984, and the United Nations Environment Programme, Urban Air Pollution: 1973-1980, World Health Organization, Geneva.

World Resources Institute, 1988, and the International Institute for Environment and Development in collaboration with the United Nations Environment Programme, World Resources 1988-1989: An Assessment of the Resource Base that Supports the Global Economy, Basic Books, Inc., New York. 
DATE

FILMED

8127192 
